\title{
The Effect of Job Autonomy on Employee Innovative Behavior: The Role of Job Satisfaction as Intervening Variable
}

\author{
Nursiha Ramadani Nasution', Zulkifli Musannip Efendi Siregar ${ }^{2}$, Pristiyono $^{3}$ \\ ${ }_{1,2,3}$ Universitas Labuhanbatu, Rantauprapat, Indonesia \\ nursiharamadani@gmail.com
}

\begin{abstract}
Employee job satisfaction in covid-19 conditions and situations that need to be considered are those employees who work in Micro, Small, and Medium Enterprises (MSMEs) units. Interestingly, peeling employee job satisfaction in scientific studies is expected to provide various inputs to business managers or business owners who are controlled through work autonomy and innovative behavior in organizations. This research was conducted on the community in the Rantaurapat area around. The questionnaires collected were 100 questionnaires, the respondents in this study were 100 respondents. This research is research using quantitative methods, the researcher in this case distributes questionnaires to get data from respondents using Google Form, and then the data is analyzed using the help of SPSS 23 and AMOS version 23. Based on the results of research and discussion that have been trusted in the previous section, it can be concluded that work autonomy can increase job satisfaction in employees and be able to increase employee innovation behavior. The firm that can provide opportunities for their employees to develop and innovate without feeling pressured at work will provide satisfaction to these employees in working and advancing the company. The results of this study also indicate that job satisfaction did not mediate the effect of job satisfaction on innovation behavior, because the direct effect of job autonomy on innovative behavior was greater than indirect effect via job satisfaction.
\end{abstract}

\section{Keywords}

job autonomy; innovative behavior; job satisfaction

\section{Introduction}

Micro, Small and Medium Enterprises (MSMEs) are at the forefront of the development of a country, this is supported by research (Feranita, 2015) MSMEs are the main and vital sector to create community growth and are also able to open new types of jobs. MSMEs are very easy to adapt to an unstable community economy amidst changing market demands, these MSMEs are able to create large enough jobs to encourage the progress of the community's economy which is currently experiencing a decline due to the Covid-19 pandemic. During a pandemic like now, there are so many companies that layoff employees, so that many employees lose their jobs and cause unemployment to increase. The existence of MSMEs has so far succeeded in contributing two-thirds of income by $43 \%$ and is a solution in reducing unemployment(Pedauga et al., 2021).

During the Covid-19 era like this, MSMEs had a big role in driving the economy which was currently in a very declining state as a result of the policies taken by the Government to carry out a lockdown. MSMEs have a vital role in business and economic progress to reduce unemployment and poverty rates. In the business world in the era of globalization, business competition is inevitable for anyone, so that MSMEs (Micro, Small and Medium Enterprises) must be able to have advantages in their fields and must always 
be able to be ready to have the latest innovations to advance and develop their business so that they are able to have potential. high effort and able to compete. Good human resources and high potential are needed so that MSMEs have more advantages and are able to compete in the midst of the large number of small businesses that are opened, proper human resource management is in the predetermined corridors so that they can develop properly (Siregar et al., 2020).

One of the efforts needed to improve the innovative behavior of employees in MSME organizations is to adopt work autonomy. Work autonomy is meant in terms of giving authority to employees of an UMKM, for example, the authority to make decisions related to increasing employee job satisfaction. With the authority regarding work autonomy within MSMEs, it will open up the role of employees in providing new ideas that they work on in order to be able to develop business and achieve common goals. The application of work autonomy in the organization is to provide freedom and flexibility to employees in carrying out work in accordance with applicable regulations so that employees do not feel pressured at work. Employees are given the freedom to innovate to create the latest products, with this work autonomy employees are considered capable of carrying out their work. The implementation of work autonomy within the company indicates that companies with strong trust in employees are closely related to all the skills and abilities of employees in completing their work properly. Good work autonomy is automatically able to control the emotional level of employees indirectly if they do not have work autonomy at all. One of the important things in work is the implementation of work autonomy, this is supported by the results of previous studies which show a positive relationship between work attitudes and work motivation(Huda dan Bahri, 2017).

It is realized that in the Covid-19 situation, many MSME players are faced with various problems, both problems from within the company itself and from outside the company, so that this affects the development and progress of the business being managed. The difficulty of the economy during this Pandemic period made more and more business actors increase their income, the number of employees who were dismissed made business actors soar and this certainly had a huge impact on competition which was getting more and more tighter. Fierce competition between MSME business actors has now begun to shift and are competing to make various breakthroughs in the form of innovation as the key to maintaining the existence of their business. The UMKM business without an innovative will hamper the achievement of the competitive advantage of the UMKM itself. Feranita, (2015) innovative means a positive activity that needs to be done in order to create value through knowledge and production growth.

The formation of innovative employee behavior is determined by the existence of work autonomy, with the autonomy of work, employees can be given the freedom to convey new ideas to their colleagues or superiors. Employees can apply or channel their ideas or ideas in their place of work. With the freedom to innovate, employees become more developed and more advanced in thinking about what things they will do to maintain the existence of the business and advance the business. This also affects the job satisfaction felt by the employee, because if the job satisfaction felt by the employee is sufficient or fulfilled according to what he is doing, this will have a positive impact on employee innovative behavior. The problem or factor that hinders employees from channeling innovative ideas is the lack of knowledge from the employee, the great feeling of lack of confidence from the employees themselves, so that employees are afraid to take risks, fear that the ideas submitted are criticized and lack of effort to create and develop. Maintaining employee job satisfaction in covid-19 conditions does not only occur in large companies, employee job satisfaction in MSME organizations is much more interesting to study, this is 
because each UMKM unit has different employees so it requires strong analysis, although in general Employee job satisfaction at both the company and the MSME organization is measured by salary, attention and work environment so that the employee will do everything possible to give everything he can to advance the firm. Huda dan Bahri, (2017) said that job satisfaction felt by employees can affect employee loyalty at work and motivate employees to be even more active at work.

\section{Review of Literature}

\subsection{Micro, Small and Medium Enterprises}

Micro, small and medium enterprises (MSMEs) are a type of business that plays a role in various business fields that touch the interests of the community as well as support the national economy. Through micro, small and medium enterprises (MSMEs) it is able to provide opportunities to create new jobs in small and medium scale, as well as become a source of state income through taxes. The role of micro, small and medium enterprises (MSMEs) as a business sector that is able to quickly and easily create jobs compared to other business sectors. Micro, small and medium enterprises (MSMEs) also have an important role for the Indonesian economy, namely, to increase employment opportunities, encourage a more equitable economy, encourage the economy in difficult periods and be able to meet needs on target(Sunariani et al., 2017).

\subsection{Job Autonomy and Job Satisfaction}

Work autonomy can be defined as the extent to which an organization or company can provide freedom in work and flexibility to individual employees in completing their work in accordance with the work procedures used (Huda dan Bahri, 2017). Providing freedom and flexibility to employees as work autonomy itself does not aim to give absolute authority to employees in controlling the organization including in decision making, but to make employees as comfortable as possible at work, so that a sense of responsibility in themselves towards work becomes a workload that must be completed. Thus, it is possible to implement work autonomy in MSME organizations because organizations within MSMEs are very vulnerable to turnover so that the work autonomy strategy can be one way of increasing employee job satisfaction with the trust it receives.

The availability of work autonomy within companies or MSME organizations can provide a strong signal that their superiors have given confidence in the skills and abilities of employees to carry out their jobs properly. The results of study by Sugiyarti dan Meiliana, (2018) show that job satisfaction has a positive and significant effect on work autonomy. Based on the results of the analysis of previous research, it shows that Work Autonomy has a positive and significant effect on Job Satisfaction (Huda dan Bahri, 2017). Saragih, (2011) $\mathrm{n}$ his research shows that there is a positive and significant influence between job autonomy on job satisfaction and performance. The instrument of work autonomy was adopted from Maiti \& Bidinger, (1981) as many as 6 indicators, namely authority, flexibility, recognized work results, given freedom, paying attention to work capacity, and being able to complete work.

H1: Job autonomy has a significant effect on job satisfaction. 


\subsection{Job Satisfaction and Innovative Work Behavior}

The job satisfaction felt by employees will be seen when the work that has been done is in accordance with the expected results of what they have done (Siregar et al., 2020). The existence of a job suitability with what has been planned properly by employees in the job is closely related to the assessment, sensitivity, feelings or attitudes of employees towards their work related to the work environment. Therefore, job satisfaction for employees in companies or MSME organizations can be identified from the final results of the work, according to research by Astuti et al., (2019) that job satisfaction is the result of things that have been fulfilled according to their wishes and needs through work activities.

Job satisfaction is also related to the general attitude towards a person's work, the difference between the amount of reward a worker receives and the amount they believe they should receive. The belief that satisfied employees are more productive than unsatisfied employees is a basic tenet among leaders. (Rafida and Julham, 2020)

The fulfillment of employee job satisfaction in the company or MSME organization has a positive impact on employee behavior or attitudes, where employees will always try more to maximize their abilities in every job they receive. The results of the study by Sujarwo dan Wahjono, (2017) prove that innovative behavior has a positive effect on job satisfaction, if employees are able to create creative ideas within the company, job satisfaction automatically leads to big things. The existence of this innovative behavior will increase job satisfaction (Astuti et al., 2019). Research results from Prayudhayanti, (2014) also show that job satisfaction has a significant effect on innovative behavior. The instrument of job satisfaction was adopted from Hargono, (2008) as many as 10 indicators, namely new experience, work according to ability, salary, salary increase based on achievement, performance based assessment, increase in employment, superiors provide motivation, superiors provide solutions, get support from colleagues and mutual help between workers.

$\mathrm{H} 2$ : Job satisfaction has a significant effect on innovative behavior.

\subsection{Job Autonomy and Innovative Work Behavior}

Structured innovative behavior requires commitment, both in the form of management involvement and developing technical and non-technical supporting factors that are able to encourage innovative behavior in every job role (Soebardi, 2012). Innovative behavior is the individual behavior of every employee aimed at reaching the introduction stage or trying to introduce new and useful ideas, processes, products or procedures for work. Employees are challenged to be able to create new ideas or ideas that can provide benefits or profits to the company where they work. Work behavior is innovative, a series of work activities that are gradually carried out by workers in developing and improving effective work behavior (De Jong dan Den Hartog, 2010).

Employee innovative behavior is needed for ongoing business development, with the development of new ideas it will provide benefits for the company if these ideas can be applied properly and are able to compete to increase company profits. Meanwhile, work autonomy supports the hypothesis in this study that theoretically and empirically, the role of job design in innovative implementations related to performance can be distinguished in practice (Burcharth et al., 2017). This explains that if the company can implement work autonomy effectively and efficiently, the company indirectly has innovative behavior in organization, where the aim is to improve employee performance in the future. Research results from (Swaroop dan Dixit, 2018) also state that there is a positive influence between work autonomy on innovative behavior. Research by Siregar et al.,(2021) also explains 
that there is a positive influence that work autonomy has a positive effect on innovative behavior. Instruments of innovative behavior are adopted from Bobo, (2017) as many as 6 indicators, namely looking for new methods, applying ideas, trying to get ideas accepted, trying to get idea approval, trying to realize ideas and looking for creative new things. H3: Job autonomy has a significant effect on innovative behavior.

\section{Research Methods}

The research development applies quantitative research methods, where the researcher in this case distributes questionnaires to obtain data from respondents, the questionnaire is compiled into a Google Form that is related to the variable being studied, and then the data is analyzed using the help of SPSS 23 and AMOS version 23. The population in this study were 100 MSME employees in the Ajamu Market, Labuhanbatu Regency. The sample selection is done by using total sampling technique, so that the number of samples is the same as the total population, namely 100 respondents. The variables in this study consisted of three variables, namely work autonomy, innovative behavior and job satisfaction. instruments of work autonomy were adopted from Maiti \& Bidinger, (1981) as many as 6 indicators, instruments of innovative behavior were adopted from Bobo, (2017) as many as 6 indicators, instruments of job satisfaction were adopted from Hargono, (2008) as many as 10 indicators . Researchers in this case use a path analysis approach to be able to determine the effect of the relationship between variables.

\section{Results and Discussion}

\subsection{Hypotheses Testing Results}

This study has three hypotheses that will be tested using the path analysis technique. Path analysis is the development of regression analysis to determine the quality relationships between variables that have been previously determined based on theory and other supporting factors that are considered relevant, such as journals in the form of previous studies. In order to know whether a hypothesis is accepted or not, it must be seen from the value of C.R or t count $>1.96$ and a significance value of probability $<0.05$ (Byrne, 2013). The results of hypothesis testing in this study can be seen in table 1 below;

Table 1. Hypotheses Testing

\begin{tabular}{|c|c|c|c|c|c|c|}
\hline Variables & & Estimate & S.E. & C.R. & $\mathrm{P}$ & Decision \\
\hline Job Satisfa & $<---\quad$ Job & .533 & .146 & 3.657 & $* * *$ & ted \\
\hline Innovative Beha & $<---\quad$ Job Autonomy & .492 & .100 & 4.938 & $* * *$ & Accepted \\
\hline Innovative Behavior & $<---\quad$ Job Satisfaction & .135 & .064 & 2.090 & .037 & Accepted \\
\hline
\end{tabular}

Source: Data Processing, 2021

Based on hypothesis testing as in table 1, it shows that the hypothesis in the study is accepted. This means that there is a positive and significant influence between exogenous variables on endogenous variables.

The test results on the first hypothesis between work autonomy have a significant effect on job satisfaction. The results of this study indicate that the t value (CR) is 3,657> 1.96 and the P-value is $0.000<0.05$. This means that the work autonomy variable has a positive and significant effect on job satisfaction. In testing the first hypothesis, it can be seen that there is a significant influence between work autonomy on job satisfaction at MSMEs in Rantauprapat. This means that if work autonomy at MSMEs is enforced, it will 
encourage employees to be able to control their work and be more able to be responsible for their work without feeling pressured so that they can bring peace to work and can provide increased job satisfaction for employees. This study is in accordance with research from Bradley et al.,(2003) that work autonomy is a very significant determinant of job satisfaction (Naqvi et al., 2013) also found that if job autonomy increases, job satisfaction also increases.

The test results on the second hypothesis between work autonomy have a significant effect on employee innovative behavior. The results of this study indicate that the t value $(\mathrm{CR})$ is $4,938>1.96$ and the $\mathrm{P}$-value is $0.000>0.05$. This means that the work autonomy variable has a positive and significant effect on employee innovative behavior. The results of testing the second hypothesis show that there is a positive and significant influence between work autonomy on innovative behavior of employees at MSMEs in Rantauprapat. This means that the work autonomy given to employees will affect employee innovative behavior, with this work autonomy, employees are able to create new creative and innovative ideas to be developed and applied, the results of research Swaroop \& Dixit, (2018) also show a positive influence. And significant between work autonomy and innovative behavior.

The results of testing on the third hypothesis between job satisfaction have a significant effect on employee innovation. The results of this study indicate that the t value $(\mathrm{CR})$ is $2.090>1.96$ and the $\mathrm{P}$-value is $0.037<0.05$. This means that the job satisfaction variable has a positive and significant effect on employee innovative behavior. Job satisfaction has also been shown to have a positive and significant influence on innovative behavior of employees at MSMEs in Rantauprapat. This means that if the higher the employee's innovative behavior, the job satisfaction felt by the employee will also increase, research conducted by (Sujarwo \& Wahjono, 2017) shows that there is a significant influence between job satisfaction and innovative employee behavior. Job satisfaction testing as a mediation between work autonomy and innovative behavior has also been carried out. The results showed that job satisfaction mediated the relationship between work autonomy and employee innovative behavior in a positive and significant manner.

\section{Conclusion}

From the results and discussion conducted, it is evident that through the results of this study it can be concluded that job autonomy, innovative behavior and job satisfaction for MSME employees are so important, so that the results of the study have an empirical conformity with the hypothesis testing carried out. The success of this research indicates that in the midst of the Covid-19 disaster, every company as a business actor must be able to provide opportunities for employees to act and act with flexible work autonomy so that employees with all their reasoning will work with innovative behavior which will have an impact on job satisfaction. The results of this study also indicate that job satisfaction is able to positively and significantly mediate the effect of job satisfaction on innovative employee behavior. Based on the research results that have been obtained, employees are the most important factor and employees have an important role in advancing and developing MSMEs in Rantauprapat. So we need employees who are able to innovate and be creative to advance MSMEs in Rantauprapat, the results of this study indicate that job satisfaction has the greatest influence on employee innovative behavior. With this the authors recommend to further improve job satisfaction for employees so that employees are able to provide new innovations for companies that are more advanced and developing. 


\section{References}

Abdullah, Z. (2018). An analysis of factors affecting the investment growth of Indonesian Islamic insurance. 4, 71-81.

Astuti, T. P., Sitawati, R., \& Tukijan. (2019). Pengaruh Kreativitas dan Perilaku Inovatif Terhadap Kinerja Karyawan Dengan Kepuasan Kerja Sebagai Variabel Mediasi (Studi Pada Hotel Pandanaran Semarang). Jurnal Ekonomi Manajemen Dan Akuntansi, 47, 53-64.

Bobo, J. (2017). Peningkatan perilaku inovatif melalui komitmen organisasi dan kepuasan kerja. Jurnal Ekonomi Dan Bisnis.

Bradley, S., Taylor, J., \& Nguyen, A. (2003). Job autonomy and job satisfaction: new evidence. Management, February, 1-24. https://doi.org/10.1017/CBO9781107415324.004

Burcharth, A., Præst Knudsen, M., \& Søndergaard, H. A. (2017). The role of employee autonomy for open innovation performance. Business Process Management Journal, 23(6), 1245-1269. https://doi.org/10.1108/BPMJ-10-2016-0209

Byrne, B. M. (2013). Structural Equation Modeling With AMOS. In Structural Equation Modeling With AMOS. https://doi.org/10.4324/9781410600219

De Jong, J., \& Den Hartog, D. (2010). Measuring innovative work behaviour. Creativity and Innovation Management, 19(1), 23-36. https://doi.org/10.1111/j.14678691.2010.00547.x

Hargono. (2008). No Title. Kuesioner Responden Yang Terhormat, Saya Edwin Hargono Dari Mahasiswa Fakultas Ekonomi Dan Bisnis Jurusan Manajemen Angakatan 2008 Unika Soegijapranata, Memohon Kesediaan Bapak / Ibu / Saudara Untuk Mengisi Angket Kuesioner Yang Nantinya Berguna Untuk M.

Huda, S., \& Bahri, S. (2017). Pengaruh Otonomi Kerja Terhadap Locus Of Control Dengan Kepuasan Kerja Sebagai Pemediasi ( Pada Kantor Dinas Pendidikan Provinsi Aceh ). Jurnal Ilmiah Mahasiswa Ekonomi Manajemen, 1(3), 195-212.

Lucero, B., Ceballos, P. A., Muñoz-Quezada, M. T., Reynaldos, C., Saracini, C., Baumert, B. O., \& Wang, X. (2019). Validity and Reliability of an Assessment Tool for the Screening of Neurotoxic Effects in Agricultural Workers in Chile. BioMed Research International, 2019. https://doi.org/10.1155/2019/7901760

Maiti, \& Bidinger. (1981). 済無No Title No Title. Journal of Chemical Information and Modeling, 53(9), 1689-1699.

Naqvi, S. M. M. R., Ishtiaq, M., Kanwal, N., \& Ali, M. (2013). Impact of Job Autonomy on Organizational Commitment and Job Satisfaction: The Moderating Role of Organizational Culture in Fast Food Sector of Pakistan. International Journal of Business and Management, 8(17), 92-102. https://doi.org/10.5539/ijbm.v8n17p92

Nungky Viana Feranita. (2015). Peran Inovasi dalam Memediasi Pengaruh Kepemimpinan dan Kekuatan Kompetitif Industri terhadap Kinerja Usaha Kecil dan Menengah. Majalah Ekonomi, XIX(1), 47-59.

Pedauga, L., Sáez, F., \& Delgado-Márquez, B. L. (2021). Macroeconomic lockdown and SMEs: the impact of the COVID-19 pandemic in Spain. Small Business Economics. https://doi.org/10.1007/s11187-021-00476-7

Prayudhayanti, B. N. (2014). Peningkatan Perilaku Inovatif Melalui Budaya Organisasi. Jurnal Ekobis, 15(2), 19-32.

Rafida, T and Julham, T. (2020). Relationship Following Training and Achievement Motivation with Work Satisfaction Learning Citizens in Mandir Institution Courses 
and Training of Tanjung Balai City. Budapest International Research and Critics Institute-Journal (BIRCI-Journal). P. 598-604

Saragih, S. (2011). The Effects of Job Autonomy on Work Outcomes: Self Efficacy as an Intervening Variable. International Research Journal of Business Studies, 4(3), 203215. https://doi.org/10.21632/irjbs.4.3.203-215

Siregar, Z. M. E., Sujana, F. R., Pranowo, A. S., \& Supriadi, Y. N. (2021). Job autonomy and innovative work behavior of marketing employees in the automotive industry in Indonesia: The mediating role of organizational commitment. Quality - Access to Success, 22(180), 97-102.

Siregar, Z. M. E., Syahputra, R., \& Nasution, S. L. (2020). Pengaruh Keadilan Organisasional terhadap Komitmen Organisasi dengan Mediasi Kepuasan Kerja. JSHP : Jurnal Sosial Humaniora Dan Pendidikan, 4(2), 82-92. https://doi.org/10.32487/jshp.v4i2.833

Soebardi, R. (2012). Perilaku Inovatif. Jurnal Psikologi Ulayat, 1(1), 57-74. https://doi.org/10.24854/jpu12012-10

Sugiyarti, G., \& Meiliana, T. W. (2018). Analisis Otonomi Kerja Terhadap Komitmen Organisasi Dan Kepuasan Kerja Dengan Peran Moderasi Budaya Organisasi Pada Pedagang Kaki Lima Di Perumnas Tlogosari Kota Semarang. Jurnal Ilmiah UNTAG Semarang, 7(2), 90-96.

Sujarwo, A., \& Wahjono. (2017). Pengaruh Motivasi Kerja dan Perilaku Inovatif Terhadap Kinerja Karyawan Dengan Kepuasan Kerja Sebagai Variabel Mediasi (Studi Kasus pada LKP ALFABANK Semarang). Infokam, 1, 63-71.

Sunariani, N. N., Suryadinata, A. O., \& Mahaputra, I. I. R. (2017). Pemberdayaan usaha mikro kecil dan menengah (umkm) melalui program binaan di provinsi Bali. Jurnal Ilmiah Manajemen Dan Bisnis, 2(1), 1-20.

Swaroop, P., \& Dixit, V. (2018). Employee engagement, work autonomy and innovative work behaviour: An empirical study. International Journal of Innovation, Creativity and Change, 4(2), 158-176.

Yilmaz, M., Dişsiz, G., Demir, F., Irız, S., \& Alacacioglu, A. (2017). Reliability and validity study of a tool to measure cancer stigma: Patient version. Asia-Pacific Journal of Oncology Nursing, 4(2), 155. https://doi.org/10.4103/apjon.apjon_10_17 